
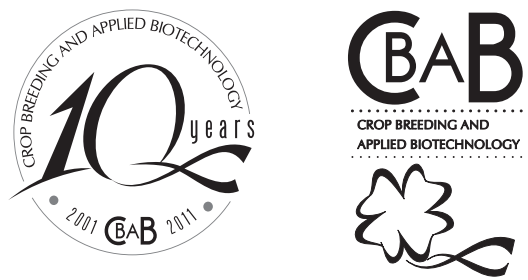

\title{
Diallel analysis in white oat cultivars subjected to water stress
}

Guilherme Ribeiro $^{1 *}$, Gustavo da Silveira ${ }^{1}$, Maraisa Crestani ${ }^{1}$, Rafael Nornberg ${ }^{1}$, Henrique de Souza Luche ${ }^{1}$, Itamara Mezzalira ${ }^{1}$, Fernando Irajá Félix de Carvalho ${ }^{1}$ and Antônio Costa de Oliveira ${ }^{1}$

Received 5 May 2010

Accepted 6 August 2010

\begin{abstract}
The goal of this work was to determine the combining ability of three white oat parental genotypes (UPF 18, URS21 and URS 22) and to estimate the heterosis of $F_{1}$ hybrids in two conditions, with and without water stress. The results indicate a large effect of the environment on the evaluated characters (cycle, leaf area, plant stature, grain yield per plant, main panicle weight and number of grains of the main panicle). The condition without stress was the most efficient for the selection of superior genotypes. Based on the general and specific combining ability, the cultivar URS 22 was shown to be indicated for cycle and stature reduction, while UPF 18 lead to increases in leaf area, main panicle weight and number of grains of the main panicle. The specific cross URS $22 x$ URS 21 was the best for the selection of superior genotypes.
\end{abstract}

Key words: Avena sativa L.; combining ability; heterosis.

\section{INTRODUCTION}

Oat (Avena sativa L.) is among the six major cereals worldwide, being the fifth most cultivated cereal in Brazil, with an average area of 125 thousand hectares. The current average yield in Brazil is $1,946 \mathrm{~kg} \mathrm{ha}^{-1}$ (Faostat 2009). However, the yield in some areas of the Southern Region are below average due to adverse environmental conditions.

Plant breeding programs have concentrated their efforts in the development of high genetic potential and stable performance in diverse environments. The evaluation of the genetic potential of cultivars and their combining ability are essential to the program's success, since good hybrids generate superior segregating populations (Kurek et al. 2001).
In oat breeding, as well as for any other species, the correct selection of parental genotypes is an important step for the development of genotypes adapted to the different environmental conditions. The understanding of the genetic basis allows the improvement in the oat's ability to tolerate abiotic stresses. Reports have indicated that genetic gains for grain yield are obtained more efficiently in superior environments, i.e., those leading to better yields. Also, the task of developing genotypes with a higher yield under stress has been a difficult one, due to the lower heritability of the character under selection (Byerlee and Moya 1993, Trethowan et al. 2002).

Diallel crosses and the evaluation of combining ability in white oat are limited by the difficulty in performing artificial crosses and the need for the evaluation of a high number of parental genotypes (Vieira et al. 2005). The

\footnotetext{
${ }^{1}$ Universidade Federal de Pelotas (UFPel), Centro de Genômica e Fitomelhoramento (CGF), Faculdade de Agronomia "Eliseu Maciel” (FAEM), 96.010-900, Pelotas, RS, Brazil. *E-mail: guilherme.tche@gmail.com
} 
general and specific combining ability estimates allow the prediction of favorable alleles in a given genotype (Castiglioni et al. 1999). Also, the estimate or quantification of heterosis is an important component of the combining ability; however the heterosis effects vary as a function of the selection environment (Ud-Din et al. 1992).

Parental genotypes with high general and specific combining ability were identified by Lorencetti et al. (2005), using diallel analyses in white oat. Regarding heterosis, not always did parental genotypes with high averages result in superior hybrids (Lorencetti et al. 2006). The stability of GCA and SCA for plant grain yield in two years of wheat cultivation showed that GCA was not affected by years, while SCA was otherwise strongly affected (Valério et al. 2009).

The present work had as its objective to perform diallel crosses between three white oat cultivars in order to determine GCA, SCA and $\mathrm{F}_{1}$ hybrid heterosis under water stress conditions.

\section{MATERIAL AND METHODS}

The experiment was performed in the greenhouse belonging to the Centro de Genômica e Fitomelhoramento from the Universidade Federal de Pelotas (UFPel), located in Capão do Leão County, winter 2008. Three oat cultivars: UPF 18, URS 21 and URS 22, and the three hybrids resulting from the diallel crosses between them were studied. The hybrid seeds were obtained in the cold season of 2007, through the artificial crossing of parental genotypes reciprocally, since no maternal effect was ever detected in white oats.

The parental and $\mathrm{F}_{1}$ hybrid genotypes were sown in the cold season of 2008 and conducted in random blocks with split plot design and three repetitions, using the factors water stress (with and without stress) and genotype (UPF 18, URS 21, URS 22, UPF 22 x URS 21, UPF 21 x URS 18 and URS 22 x UPF 18) treated as plots and subplots, respectively.

The following characters were evaluated: 1) cycle CYCLE (expressed in days, period between the emergence and maturation); 2) flag leaf area - LA (measured in $\mathrm{cm}^{2}$, obtained by the product between flag leaf width and length); 3) plant stature - PST (measured in cm, equivalent to the distance between the soil and panicle tip, excluding the awns); 4) grain yield per plant - GYP (measured in grams, obtained from the grain weight); 5) main panicle weight - MPW (measured in grams) and; 6) number of grains of the main panicle-NGP.
The plastic recipients of each plot were filled with soil already corrected for fertility. Nitrogen fertilization was performed at the beginning of tilling, by applying $100 \mathrm{~kg}$ $\mathrm{ha}^{-1}$ of urea. Two fungicide applications were performed using Tebuconazole (Folicur, $750 \mathrm{ml} \mathrm{ha}^{-1}$ ), one at the onset of the disease and another 20 days after. Also, two insecticide applications were performed using Malationa (Malation $500 \mathrm{CE}, 600 \mathrm{ml} \mathrm{ha}^{-1}$ ) at an interval of 15 days after the detection of insects. The pots were maintained wet until the beginning of flowering. After the flowering period, the genotypes were subjected to the following treatments: i) without water stress, where the soil was maintained close to its maximum water storing capacity (field capacity) by irrigating the plants every other day and ii) treatment without water stress, where the recipients were watered every 14 days up to their field capacity.

Based on the analysis of variance, the square sum of treatments were partitioned into general (GCA) and specific (SCA) combining ability. For the partitioning, the method 2 of Griffing (Griffing 1956) was used, based on the statistical model of fixed effects: $Y_{i j}=\mu+G_{i}+G_{j}+S_{i j}$ $+\bar{\varepsilon}_{i j}$, where: $Y_{i j}$ : hybrid combination $(i \neq \mathrm{j})$ or parental $(\mathrm{i}=\mathrm{j})$ mean value; $\mu$ : general mean; $G_{i}$ and $G_{j}$ : effects of the general combining ability associated to the $\mathrm{i}$ and $\mathrm{j}$-ith parental, respectively; $S_{i j}$ : specific combining ability effect for the crosses between parents $\mathrm{i}$ and $\mathrm{j}(\mathrm{i} \neq \mathrm{j}) ; \bar{\varepsilon}_{i j}$ : mean experimental error. The estimate of heterosis was performed based on a model similar to the one proposed by Matzinger et al. (1962) and described by Gardner and Eberhart (1966) through the expression: $H_{l}(\%)=[(-) /]^{*} 100$, where: $H_{l}$ : heterosis regarding the parental mean; $\bar{F}_{l}$ : hybrid mean; $\overline{M P}$ : parental mean [(parental $1+$ parental 2$) / 2]$. All the analyses were performed with the Genes software (Cruz 2006).

\section{RESULTS AND DISCUSSION}

Since significant differences $(\mathrm{P} \leq 0.05)$ were detected between the treatments with and without water stress for all characters, the genotypes (parents and $\mathrm{F}_{1}$ hybrids) were subjected to an analysis of variance for each stress condition. There were significant differences $(\mathrm{P} \leq 0.05)$ for all evaluated characters, with the exception of grain yield per plant (PG) and main panicle weight (MPW) in the water stress condition.

The square sum for genotypes was partitioned into GCA and SCA (Table 1). It was observed that GCA and SCA effects were significant $(\mathrm{P}<0.05)$ for all characters in 
Diallel analysis in white oat cultivars subjetecd to water stress

Table 1. Summary of the analysis of variance for each water stress condition, for a diallel cross with three cultivars (URS 22 , URS 21 and UPF 18) and their respective $F_{1}$ hybrid combinations (without reciprocals) for six characters ${ }^{1}$ in white oat

\begin{tabular}{|c|c|c|c|c|c|c|c|c|c|c|c|c|c|}
\hline \multirow{3}{*}{ SV } & \multirow{3}{*}{ df } & \multicolumn{12}{|c|}{ Without stress } \\
\hline & & \multicolumn{2}{|c|}{ CYCLE } & \multicolumn{2}{|c|}{ LA } & \multicolumn{2}{|c|}{ PST } & \multicolumn{2}{|c|}{ GYP } & \multicolumn{2}{|c|}{ MPW } & \multicolumn{2}{|c|}{ NGP } \\
\hline & & MS & $\phi$ & MS & $\phi$ & MS & $\phi$ & MS & $\phi$ & MS & $\phi$ & MS & $\phi$ \\
\hline Genotype & 5 & $8.00^{*}$ & - & $997.27 *$ & - & $475.95^{*}$ & - & $9.5^{*}$ & - & $1.88^{*}$ & - & $1472.88^{*}$ & - \\
\hline $\mathrm{GCA}_{(\mathrm{g})}$ & 2 & 3.8 & 0.40 & 1406.21 & 255.87 & 550.93 & 105.61 & 4.89 & -0.30 & 4.13 & 0.76 & 3159.56 & 507.71 \\
\hline $\mathrm{SCA}_{(\mathrm{s})}$ & 3 & 10.8 & 8.99 & 691.31 & 564.47 & 425.96 & 403.08 & 12.57 & 6.17 & 0.38 & 0.05 & 348.42 & -272.58 \\
\hline Error & 10 & \multicolumn{2}{|c|}{1.81} & \multicolumn{2}{|c|}{126.84} & \multicolumn{2}{|c|}{22.88} & \multicolumn{2}{|c|}{6.40} & \multicolumn{2}{|c|}{0.33} & \multicolumn{2}{|c|}{621.00} \\
\hline \multirow[t]{2}{*}{ CV (\%) } & & \multicolumn{2}{|c|}{1.12} & \multicolumn{2}{|c|}{16.16} & \multicolumn{2}{|c|}{4.18} & \multicolumn{2}{|c|}{29.02} & \multicolumn{2}{|c|}{19.53} & \multicolumn{2}{|c|}{28.75} \\
\hline & \multirow{3}{*}{ df } & \multicolumn{12}{|c|}{ With stress } \\
\hline \multirow[t]{2}{*}{ SV } & & \multicolumn{2}{|c|}{ CYCLE } & \multicolumn{2}{|c|}{ LA } & \multicolumn{2}{|c|}{ PST } & \multicolumn{2}{|c|}{ GYP } & \multicolumn{2}{|c|}{ MPW } & \multicolumn{2}{|c|}{ NGP } \\
\hline & & MS & $\phi$ & MS & $\phi$ & MS & $\phi$ & MS & $\phi$ & MS & $\phi$ & MS & $\phi$ \\
\hline Genotype & 5 & $16.10^{*}$ & - & $353.09^{*}$ & - & $173.21^{*}$ & - & 1.06 & - & 0.39 & - & $499.88^{*}$ & - \\
\hline $\mathrm{GCA}_{(\mathrm{g})}$ & 2 & 15.20 & 2.68 & 831.23 & 142.77 & 35.11 & -6.30 & 0.50 & 0.01 & 0.05 & -0.03 & 50.77 & -45.88 \\
\hline $\mathrm{SCA}_{(\mathrm{s})}$ & 3 & 16.70 & 14.89 & 34.33 & -83.04 & 265.28 & 198.66 & 1.44 & 1.00 & 0.61 & 0.39 & 799.29 & 519.11 \\
\hline Error & 10 & \multicolumn{2}{|c|}{1.81} & \multicolumn{2}{|c|}{117.37} & \multicolumn{2}{|c|}{66.62} & & & & & 280 & \\
\hline CV (\%) & & & & & & & & 51 & & & & 26 & \\
\hline
\end{tabular}

$\mathrm{MS}=$ mean square. $\phi_{(\mathrm{g})}$ and $\phi_{(\mathrm{s})}=$ estimate of the component associated to general and specific combining ability, respectively. * Significant at $5 \%$ probability by the $\mathrm{F}$ test. CV $(\%)=$ coefficient of variation. Cycle (CYCLE), in days; flag leaf area (LA), in $\mathrm{cm}^{2} ;$ plant stature (PST), in $\mathrm{cm}^{2}$ grain yield per plant (GYP), in grams; main panicle weight (MPW), in grams; and number of grains of the main panicle (NGP).

the condition without stress, except for the character CYCLE. Under water stress, there were significant differences for CYCLE, LA, PST and NGP. The significance of GCA and SCA indicate the presence of variability among the GCA $\left(g_{\mathrm{i}}\right)$ effects associated with additive gene effects and among the SCA $\left(s_{i j}\right)$ effects associated with nonadditive effects. It can be observed from the analysis of variance for the characters CYCLE, PST and GYP, a predominance of non-additive gene effects in both environments. This can be confirmed by the higher values for the quadratic component associated to the SCA when compared to the GCA. However, for the remaining characters, the gene effects did not show a similar trend when subjected to the different environmental conditions.

The obtained mean values for each genotype and the diallel analysis results can aid the discussion and understanding regarding the gene effects involved in the expression of each character. For the character CYCLE, it was observed that all parents in the condition without stress showed estimates equal to or above the mean, however in the condition with stress, only the genotype URS 22 expressed an inferior performance when compared to the mean (Table 2). On Table 3, through the estimate of $\mathrm{g}_{\mathrm{i}}$, it was observed that the cultivar URS 22 exhibited a negative estimate for CYCLE. This result reveals that this cultivar can be indicated for artificial crosses aiming to reduce cycle, since this is a character of extreme importance for the white oat crop. Thus, the adjustment in plant cycle to diverse cultivating conditions can increase the grain yield potential by allowing a better use of environmental periods within short time windows, where temperature and day length are favorable to the species development (Amaral et al. 1996). In this sense, cycle reduction in white oat is considered an important adaptation character. This is due to the use of genes that reduce plant height in the crosses, leading to an increase in grain yield as a function of lodging decreases and improved harvesting indexes (Federizzi and Qualset 1989).

Plant production is closely related to the capacity of maintaining high photosynthetic rates, especially by the flag leaf, and with the intensification of grain enlargement during the reproductive period (Machado et al. 1990). For the character LA (Table 2), only the cultivar UPF 18 revealed a value higher than the general mean $\left(73.04 \mathrm{~cm}^{2}\right)$. Also, it showed the highest positive GCA values for this character, ranging from 9.17 to 8.55 on the environments without and with stress, respectively (Table 3 ). On the other hand, the genotypes URS 21 and URS 22 demonstrated negative GCA values for the character LA, with the exception of URS 21 in the condition without stress.

Reductions in plant stature can increase the yield potential of oats, as was observed in rice and wheat, when genes for dwarfness were introduced (Briggle and Vogel 1968). Thus, by reducing plant stature, one can increase nitrogen fertilizations without risking lodging and therefore increasing grain yield. Analyzing the performance of 
G Ribeiro et al.

Table 2. Means of six characters for three parental genotypes (diagonal) and their respective $\mathrm{F}_{1}$ hybrids (above diagonal) in white oat

\begin{tabular}{|c|c|c|c|c|c|c|}
\hline \multirow{2}{*}{ Parents } & \multicolumn{3}{|c|}{ Without stress } & \multicolumn{3}{|c|}{ With stress } \\
\hline & URS 22 & URS 21 & UPF 18 & URS 22 & URS 21 & UPF 18 \\
\hline & \multicolumn{6}{|c|}{ CYCLE $^{2}$ (days) } \\
\hline URS 22 & $119 \mathrm{ab}^{1}$ & $117 \mathrm{a}$ & $120 \mathrm{ab}$ & $114 \mathrm{ab}$ & $111 \mathrm{a}$ & $117 \mathrm{~b}$ \\
\hline URS 21 & & $122 \mathrm{~b}$ & $119 \mathrm{ab}$ & & $116 \mathrm{~b}$ & $117 \mathrm{~b}$ \\
\hline UPF 18 & & & $119 \mathrm{ab}$ & & & $116 \mathrm{~b}$ \\
\hline \multirow[t]{2}{*}{ General mean } & & & 119 & & & 115 \\
\hline & \multicolumn{6}{|c|}{ LA $\left(\mathrm{cm}^{2}\right)$} \\
\hline URS 22 & $40.84 \mathrm{~b}$ & $71.24 \mathrm{a}$ & $88.63 \mathrm{a}$ & $47.86 \mathrm{~b}$ & $54.70 \mathrm{ab}$ & $67.15 \mathrm{ab}$ \\
\hline URS 21 & & $68.02 \mathrm{ab}$ & $89.56 \mathrm{a}$ & & $53.70 \mathrm{ab}$ & $62.32 \mathrm{ab}$ \\
\hline UPF 18 & & & $79.92 \mathrm{a}$ & & & $77.86 \mathrm{a}$ \\
\hline \multirow[t]{2}{*}{ General mean } & & & 73.04 & & & 60.60 \\
\hline & \multicolumn{6}{|c|}{ PST $(\mathrm{cm})$} \\
\hline URS 22 & $101 \mathrm{a}$ & $113 \mathrm{ab}$ & $126 \mathrm{~cd}$ & $95 \mathrm{a}$ & $115 \mathrm{~b}$ & $105 \mathrm{ab}$ \\
\hline URS 21 & & $105 \mathrm{a}$ & $134 \mathrm{~d}$ & & $95 \mathrm{a}$ & $105 \mathrm{ab}$ \\
\hline UPF 18 & & & $120 \mathrm{bc}$ & & & $106 \mathrm{ab}$ \\
\hline \multirow[t]{2}{*}{ General mean } & & & 117 & & & 103 \\
\hline & \multicolumn{6}{|c|}{ GYP (g) } \\
\hline URS 22 & $6.71 \mathrm{c}$ & $10.34 \mathrm{a}$ & $10.42 \mathrm{a}$ & $1.43 \mathrm{a}$ & $2.48 \mathrm{a}$ & $1.27 \mathrm{a}$ \\
\hline URS 21 & & $9.20 \mathrm{ab}$ & $11.09 \mathrm{a}$ & & $0.66 \mathrm{a}$ & $1.28 \mathrm{a}$ \\
\hline UPF 18 & & & $7.39 \mathrm{bc}$ & & & $1.21 \mathrm{a}$ \\
\hline \multirow[t]{2}{*}{ General mean } & & & 9.19 & & & 1.39 \\
\hline & \multicolumn{6}{|c|}{ MPW (g) } \\
\hline URS 22 & $1.72 \mathrm{~b}$ & $2.91 \mathrm{ab}$ & $2.87 \mathrm{ab}$ & $1.37 \mathrm{a}$ & $2.45 \mathrm{a}$ & $1.75 \mathrm{a}$ \\
\hline URS 21 & & $2.83 \mathrm{ab}$ & $3.22 \mathrm{a}$ & & $1.62 \mathrm{a}$ & $1.71 \mathrm{a}$ \\
\hline UPF 18 & & & $4.19 \mathrm{a}$ & & & $1.68 \mathrm{a}$ \\
\hline \multirow[t]{2}{*}{ General mean } & & & 2.96 & & & 1.76 \\
\hline & \multicolumn{6}{|c|}{ NGP } \\
\hline URS 22 & $51 \mathrm{~b}$ & $88 \mathrm{ab}$ & $93 \mathrm{a}$ & $53 \mathrm{~b}$ & $87 \mathrm{a}$ & $56 \mathrm{~b}$ \\
\hline URS 21 & & $80 \mathrm{ab}$ & $104 \mathrm{a}$ & & $60 \mathrm{ab}$ & $55 \mathrm{~b}$ \\
\hline UPF 18 & & & $116 \mathrm{a}$ & & & $67 \mathrm{ab}$ \\
\hline General mean & & & 89 & & & 63 \\
\hline
\end{tabular}

${ }^{1}$ Means followed by the same letter do not differ by the Tukey test, at $5 \%$ probability. ${ }^{2}$ See codes for acronymous in Table 1 .

Table 3. General combining ability $\left(\mathrm{g}_{\mathrm{i}}\right)$, for six characters in three white oat parental genotypes

\begin{tabular}{lcccccc}
\hline \multirow{2}{*}{ Characters } & \multicolumn{3}{c}{ Genotypes } \\
\cline { 2 - 7 } & URS 22 & URS 21 & UPF 18 & URS 22 & URS 21 & UPF 18 \\
\cline { 2 - 7 } & -0.46 & 0.53 & -0.06 & -0.93 & -0.13 & 1.06 \\
CYCLE & -10.11 & 0.94 & 9.17 & -4.96 & -3.59 & 8.55 \\
LA & -4.98 & -1.75 & 6.74 & -0.90 & -0.86 & 1.76 \\
PST & -0.51 & 0.61 & -0.09 & 0.21 & -0.09 & -0.11 \\
GYP & -0.52 & -0.01 & 0.53 & -0.02 & 0.06 & -0.04 \\
MPW & -14.24 & -0.51 & 14.76 & -0.65 & 2.07 & -1.42 \\
NGP & & & & & & \\
\hline
\end{tabular}

${ }^{1}$ See codes for acronymous in Table 1.

parents for plant stature, one can highlight the genotypes URS 21 and URS 22, which presented mean values below the general mean for the character (Table 2). Also, as shown on Table 3, they exhibited negative $\mathrm{g}_{\mathrm{i}}$ estimates, indicating a probable contribution to the reduction of stature in their progenies. Between the two, URS 22 did show, in the environment without stress, the lower GCA value (-4.98), suggesting its use in crosses for breeding programs. 
Regarding the characters grain yield per plant (GYP), main panicle weight (MPW) and number of grains in the main panicle (NG), it can be observed that the general mean for the environment without water stress was higher than the mean for the environment with stress (Table 2).

Low GCA values usually do not differ between them, which can be explained by the masking presence of small effect complementary genes in the parental genotypes involved in the crosses (Barbieri et al. 2001). For the character MPW, it can be observed that the cultivar UPF 18 showed a high individual mean, much higher than the general mean for the environment without stress. However, its GCA value ( 0.53 ) was not very high (Table 3 ). Regarding the environment with water stress, all parents showed a performance inferior to the general mean for the character.

The correct selection of parental genotypes to form the crossing blocks is essential to the success of plant breeding programs, and the combining ability, with the presence of complementary genes, the major player in this process. Parents presenting higher GCA must be preferred to be part of crossing blocks, favoring the selection of promising homozygous lines in self crossing species (Miranda et al. 1988). A very low $\mathrm{g}_{\mathrm{i}}$ estimate indicates that the GCA of parent $i$, based on its crosses, does not differ from the diallel general mean (Cruz and Regazzi 1997). On the other hand, high positive or negative $g_{i}$ values indicate that the parent $i$ is much superior or inferior, respectively, than the other parents in the diallel scheme. Also, a higher $\mathrm{g}_{\mathrm{i}}$ could mean that the parent has higher frequency of favorable alleles for the character (Cruz and Vencovsky 1989). Regarding the character NG, only the genotype UPF 18 revealed superiority to the general mean for both environments (Table 2), showing a high and positive $\mathrm{g}_{\mathrm{i}}$ value (14.76) for this character in ideal conditions (Table 3). The values observed for the environment without stress agree with the results obtained by Lorencetti et al. (2005), where the cultivar UPF 18 showed high number of grains per panicle and high GCA.

The SCA effect is interpreted as a deviation of the hybrid to the expected based on the GCA values of its parents. Thus, low $\mathrm{s}_{\mathrm{ij}}$ values indicate a performance closer to the expected based on GCA values, while high absolute $\mathrm{s}_{\mathrm{ij}}$ values indicate a performance either higher or lower to what is expected based on GCA values. Therefore, the $s_{\mathrm{ij}}$ estimates measure non-additive gene effects, i.e., with dominance or episthatic effects (Cruz and Regazzi 1997).

The predominance of negative values on parental $\mathrm{s}_{\mathrm{ij}}$ effects indicate that these contribute to the increase in the value of the character in the progenies (Valério et al. 2009). The SCA estimates pointed to a unidirectional inheritance for LA, PST and NGP in the condition without stress and for PST under stress (Table 4). This could be explained by the fact that both parents contribute to the increase in the characters, and for the remaining characters a bidirectional inheritance was observed. None of the parental genotypes showed negative values for all characters. However, the genotype URS 22 provided the lower $\mathrm{s}_{\mathrm{ij}}$ estimates for LA (-11.96) and NGP (-8.85), indicating the possibility of contributing to the increase in these characters in both environments. For GYP, the largest contribution for the improvement of the character was obtained from UPF 18 under no stress $\left(s_{i j}=-1.61\right)$. In this sense, the larger SCA effect for grain yield was observed in the cross URS $22 \mathrm{x}$ UPF 18 (1.83), revealing that both parents could be used in breeding programs in order to develop superior progenies. To use hybrid combinations with high SCA estimates and that at least one of the parents has high $\mathrm{g}_{\mathrm{i}}$ is one of the major goals in breeding (Paini et al. 1996). This was observed for the cross URS $22 \times$ URS 21 for the character CYCLE, where the $\mathrm{s}_{\mathrm{ij}}$ values were -2.40 and -3.09 (Table 4 ), and the $g_{i}$ values of the parent URS 22 were -0.46 and -0.93 (Table 3 ). This situation caused a reduction in cycle to 117 and 111 days (Table 2), in the environments without and with water stress, respectively. For the character NGP, the same cross under stress showed $s_{i j}$ values of 22.84 and $\mathrm{a} \mathrm{g}_{\mathrm{i}}$ of 2.07 for the parent URS 21 (Tables 3 and 4) increasing the NGP to 87.30 (Table 2).

The gene effects can be interpreted by analyzing the expression of heterosis for the evaluated characters. A higher heterosis obtained from a given hybrid combination results in higher probability of rescuing superior individuals in the segregating populations (Cruz and Regazzi 1997). This can be explained by the fact that when a hybrid exhibits heterosis, one can say that a given level of dominance in the loci does exist and interferes on the character expression (Vencovsky and Barriga 1992). In the oat crop, there is a higher focus on additive effects, since they are easily transmitted to progenies and their expression is stabilized by the increase in homozygosis with the advancing of generations.

For the character CYCLE, the cross URS 22 x URS 21 was very informative, where the negative heterosis estimates must be considered in both environments, in order to obtain short cycle genotypes (Table 5). On the other hand, for plant stature, all the crosses did express positive estimates, indicating height increases in their 
G Ribeiro et al.

Table 4. Estimates for the effects of the specific combining ability (SCA) for six characters in three parental genotypes and their respective hybrids, in white oat

\begin{tabular}{|c|c|c|c|c|c|c|c|}
\hline \multirow{2}{*}{ Genotypes } & \multicolumn{7}{|c|}{ Characters } \\
\hline & Effect $\left(\mathrm{S}_{\mathrm{ij}}\right)$ & CYCLE $^{1}$ & LA & PST & GYP & MPW & NGP \\
\hline & \multicolumn{7}{|c|}{ Without stress } \\
\hline URS 22 & $\mathrm{~S}_{11}$ & 0.59 & -11.96 & -5.34 & 1.44 & -0.19 & -8.85 \\
\hline URS 21 & $\mathrm{~S}_{22}$ & 1.59 & -6.89 & -7.72 & -1.21 & -0.10 & -7.48 \\
\hline UPF 18 & $\mathrm{~S}_{33}$ & -0.20 & -11.47 & -10.30 & -1.61 & 0.17 & -2.51 \\
\hline URS $22 \times$ URS 21 & $\mathrm{~S}_{12}$ & -2.40 & 7.38 & 2.75 & 1.05 & 0.47 & 13.82 \\
\hline URS 22 x UPF 18 & $\mathrm{~S}_{13}$ & 1.20 & 16.53 & 7.92 & 1.83 & -0.09 & 3.88 \\
\hline \multirow[t]{2}{*}{ URS 21 x UPF 18} & $\mathrm{~S}_{23}$ & -0.79 & 6.40 & 12.69 & 1.38 & -0.25 & 1.14 \\
\hline & \multicolumn{7}{|c|}{ With stress } \\
\hline URS 22 & $\mathrm{~S}_{11}$ & 0.70 & -2.80 & -7.03 & -0.37 & -0.34 & -8.92 \\
\hline URS 21 & $\mathrm{~S}_{22}$ & 1.09 & 0.29 & -6.68 & -0.53 & -0.28 & -7.05 \\
\hline UPF 18 & $\mathrm{~S}_{33}$ & -1.29 & 0.14 & -0.70 & 0.05 & 0.01 & 6.85 \\
\hline URS $22 \times$ URS 21 & $\mathrm{~S}_{12}$ & -3.09 & 2.66 & 13.01 & 0.97 & 0.63 & 22.84 \\
\hline URS 22 x UPF 18 & $\mathrm{~S}_{13}$ & 1.70 & 2.95 & 1.05 & -0.21 & 0.05 & -4.99 \\
\hline URS 21 x UPF 18 & $\mathrm{~S}_{23}$ & 0.90 & -3.24 & 0.35 & 0.10 & -0.07 & -8.72 \\
\hline
\end{tabular}

${ }^{1}$ See codes for acronymous in Table 1 .

Table 5. Heterosis over the average of parental values estimates, in $\%$, for six characters evaluated in three white oat hybrids

\begin{tabular}{lccccrrr}
\hline \multirow{2}{*}{ Hybrids } & \multicolumn{7}{c}{ Characters } \\
\cline { 2 - 8 } & CYCLE $^{1}$ & LA & PST & GYP & MPW & NGP \\
\cline { 2 - 8 } & \multicolumn{7}{c}{ Without stress } \\
\hline URS 22 x URS 21 & -2.90 & 30.89 & 8.98 & 29.95 & 27.64 & 33.50 \\
URS 22 x UPF 18 & 0.84 & 46.79 & 14.24 & 47.77 & -2.84 & 11.46 \\
URS 21 x UPF 18 & -1.24 & 21.07 & 19.27 & 33.76 & -8.29 & 6.28 \\
\hline & \multicolumn{7}{c}{ With stress } \\
\hline URS 22 x URS 21 & -3.47 & 7.72 & 20.96 & 136.56 & 63.56 & 54.57 \\
URS 22 x UPF 18 & 1.73 & 6.81 & 4.89 & -4.31 & 14.69 & -6.60 \\
URS 21 x UPF 18 & 0.86 & -5.26 & 4.01 & 36.35 & 3.63 & -13.55 \\
\hline
\end{tabular}

${ }^{1}$ See codes for acronymous in Table 1.

progenies, an undesirable feature in oat breeding. Regarding the character flag leaf area, the estimates detected a critical reduction when hybrids were subjected to water stress. The heterosis estimates for the characters GYP, MPW and NGP pointed to high values in the cross URS 22 x URS 21 for both environments, with a highlight for the environment with water stress. However, the high heterosis observed for the character GYP in the environment with stress (136\%), does not express a large increase in the character when the average of the hybrid under stress is compared to the average without it (Table 2). The remaining crosses in the condition without stress showed negative heterosis estimates, i.e., did not show increases for the character MPW. The character MPW could be a viable alternative for the efficient selection of superior genotypes since high associations were found between grain yield and panicle weight (Lorencetti et al. 2005).

A higher genetic gain is expected when the selection is made in the absence of water stress, since quantitative characters such as grain yield per plant, main panicle weight and number of grains per main panicle did suffer with adverse effects of the stress, causing difficulties in the selection also, the genotypes studied can be successfully used in artificial hybridizations such as URS 22 for cycle and stature reduction and UPF 18 for increases in leaf area, main panicle weight and number of grains of the main panicle This study demonstrated that the combination URS 22 x URS 21 is very promising for the development of genotypes with short cycle and yield component increases. 


\title{
Análise dialélica em cultivares de aveia branca submetidas ao estresse hídrico
}

\begin{abstract}
RESUMO - O objetivo do trabalho foi determinar a capacidade combinatória de três genitores de aveia branca (UPF 18, URS21 e URS 22) e estimar a heterose dos híbridos $F_{1}$ nas condições, com e sem estresse hídrico. Os resultados indicaram grande efeito do ambiente sobre os caracteres avaliados (ciclo, área foliar, estatura de planta, produção de grãos por planta, massa da panícula principal e número de grãos da panícula principal), sendo o ambiente sem estresse o mais eficiente para seleção de genótipos superiores. Com base nas capacidades geral e específica de combinação, a cultivar URS 22 mostrou-se apropriada para redução do ciclo e da estatura enquanto UPF 18 exibiu incrementos da área foliar, massa da panícula principal e número de grãos da panícula principal. O cruzamento específico entre URS 22 e URS 21 mostrou ser o mais promissor para seleção de genótipos superiores.
\end{abstract}

Palavras-chave: Avena sativa L.; capacidade combinatória; heterose.

\section{REFERENCES}

Amaral AL, Carvalho FIF, Federizzi LC, Mittelmann A and Pandini F (1996) Estimativa da herdabilidade para os caracteres adaptativos ciclo e estatura de planta em aveia. Ciência Rural 26: 33-37.

Barbieri RL, Carvalho FIF, Barbosa-Neto JF, Caetano VR, Marchioro VS, Azevedo R and Lorencetti C (2001) Análise dialélica para tolerância ao vírus-do-nanismo-amarelo-dacevada em cultivares brasileiras de trigo. Pesquisa Agropecuária Brasileira 36: 131-135.

Briggel LW and Vogel OA (1968) Breeding short-stature, disease resistant wheats in the United States. Euphytica 17: 107-130.

Byerlee D and Moya P (1993) Impacts of International Wheat Breeding Research in the Developing World, 1966-1990. CIMMYT, México, D.F, 104p.

Castiglioni VBR, Oliveira MF and Arias CAA (1999) Análise da capacidade combinatória entre linhagens de girassol. Pesquisa Agropecuária Brasileira 34: 981-988.

Cruz CD (2006) Programa Genes: biometria. Universidade Federal de Viçosa, Viçosa, 382p.

Cruz CD and Regazzi AJ (1997) Modelos biométricos aplicados ao melhoramento genético. Editora UFV, Viçosa, 390p.

Cruz CD and Vencovsky R (1989) Comparação de alguns métodos de análise dialélica. Revista Brasileira de Genética 12: 425 438 .

FAOSTAT - Food and Agriculture Organization of the United Nations Statistical Database Results. Available at <http:// www.fao.org/> Assessed on Jan. 6, 2009.

Federizzi LC and Qualset CO (1989) Genetics of plant height reduction and panicle type in oat. Crop Science 29: 551-557.

Gardner CO and Eberhart SA (1966) Analysis and interpretation of the variety cross diallel and related populations. Biometrics 22: $439-452$.

Crop Breeding and Applied Biotechnology 11: 125-132, 2011
Griffing B (1956) Concept of general and specific combining ability in relation to diallel crossing systems. Australian Journal of Biological Sciences 9: 462-493.

Kurek AJ, Carvalho FIF, Assmann IC and Cruz PJ (2001) Capacidade combinatória como critério de eficiência na seleção de genitores em feijão. Pesquisa Agropecuária Brasileira 36: $645-651$.

Lorencetti C, Carvalho FIF, Benin G, Marchioro VS, Oliveira AC, Silva JAG, Hartwig I, Schmidt DAM and Valério IP (2005) Capacidade combinatória e heterose em cruzamento dialélico de aveia (Avena sativa L.). Revista Brasileira de Agrociência 11: $143-148$.

Lorencetti C, Carvalho FIF, Oliveira AC, Valério IP, Vieira EA, Silva JAG and Ribeiro G (2006) Estimativa do desempenho de progênies $\mathrm{F}_{2}$ e $\mathrm{F}_{3}$ com base no comportamento dos genitores e dos híbridos $F_{1}$ em aveia. Bragantia 65: 207-214.

Machado EC, Silveira JAG da and Bastos CR (1990) Trocas de $\mathrm{CO}_{2}$, acúmulo de fitomassa e remobilização de reservas durante o crescimento de panículas de duas cultivares de arroz. Revista Brasileira de Fisiologia Vegetal 2: 63-70.

Miranda JEC, Costa CP and Cruz CD (1988) Análise dialélica em pimentão. I. Capacidade combinatória. Revista Brasileira de Genética 11: 431-440.

Matzinger DF, Mannand TJ and Cockerham CC (1962) Diallel cross in Nicotiana tabacum. Crop Science 2: 238-286.

Paini JN, Cruz CD, Delboni JS and Scapim CA (1996) Capacidade combinatória e heterose em cruzamentos intervarietais de milho avaliados sob condições climáticas da Região Sul do Brasil. Revista Ceres 43: 288-300.

Trethowan RM, Ginkel VM and Rajaram S (2002) Progress in breeding wheat for yield adaptation in global drought affected environments. Crop Science 42: 1441-1146. 
G Ribeiro et al.

Ud-Din N, Carver BF and Clutter AC (1992) Genetic analysis and selection for wheat yield in drought-stressed and irrigated environments. Euphytica 62: 89-96.

Valério IP, Carvalho FIF, Oliveira AC, Souza VQ, Benin G, Schmidt DAM, Ribeiro G, Nornberg R and Luch H (2009) Combining ability of wheat genotypes in two models of diallel analyses. Crop Breeding and Applied Biotechnology 9: 100-107.
Vencovsky R and Barriga P (1992) Genética biométrica no fitomelhoramento. Revista Brasileira de Genética, Ribeirão Preto, 496p.

Vieira EA, Carvalho FIF, Oliveira AC, Benin G, Zimmer PD, Silva JAG, Martins AF, Bertan I, Silva G and Schmidt DAM (2005) Comparação entre medidas de distância genealógica, morfológica e molecular em aveia em experimentos com e sem a aplicação de fungicida. Bragantia 64: 51-60. 